\title{
Comparative analysis of Gram's method and PAS for the identification of Candida spp. samples from the oral mucosa
}

\author{
Análise comparativa entre o método de Gram e PAS para a \\ identificação de Candida spp. em amostras da mucosa oral
}

Cátia Martins Leite Padilha ${ }^{1}$; Bruna Lavinas Sayed Picciani ; Bruna Michalski dos Santos³; Arley Silva Júnior ${ }^{4}$; Eliane Pedra Dias

\begin{abstract}
Introduction: Candida species are part of the normal microbiota of healthy subjects, living as commensals. However, they can become pathogenic when changes in the mechanisms of host defense or disruption of anatomic barriers occur. Candidiasis is the most common fungal infection in the oral cavity, mainly caused by Candida albicans. The diagnosis is based on symptoms and clinical aspects, in association with laboratory methods. Objectives: To evaluate the sensitivity and specificity of Gram's method for Candida spp. identification in scrapes from the buccal mucosa and evaluate the degree of concordance between clinical and cytological methods in the diagnosis of oral candidiasis. Material and methods: A blind study was performed in 170 smears from patients of Hospital Universitário Antônio Pedro of Universidade Federal Fluminense (HUAP/UFF), stained by Gram $(n=57)$, periodic acid-Schiff (PAS) ( $n=$ 57) and Papanicolaou (Pap) $(n=57)$ methods. Results: The comparative analysis of the methods demonstrated a higher prevalence of Candida spp. (12\%) in PAS than in Gram staining, without statistic significance. The cytology method was positive in 93\% of the clinical diagnosis of candidiasis. Conclusion: Gram was an adequate method; however more intensive professional training would be necessary to identify the fungus morphological structures. Although Pap test is the most common method of routine cytopathologic examination, for candidiasis diagnosis PAS staining is also recommended. Thus, it is suggested that candidiasis diagnosis should be accomplished by clinical evaluation in association with cytopathological analysis based on the identification of hyphae and/or pseudohyphae.
\end{abstract}

Key words: oral cytopathology; candidiasis; Candida spp.; PAS; Gram; Papanicolaou.

\section{INTRODUCTION}

Candida species are part of the normal microbiota of healthy subjects, living as commensals, that is, they maintain seemingly neutral associations without detectable benefits or harms ${ }^{(11,20,33)}$. They can, though, become pathogenic if changes in the mechanisms of host defense or disruption of secondary anatomic barriers occur, such as in burns or invasive medical procedures ${ }^{(6,45,47)}$. Alterations of defense mechanisms may result from physiologic changes typical of childhood and old age, or associated with degenerative or neoplastic diseases, congenital or acquired immune deficiencies $^{(6,10,19)}$. Under normal circumstances, Candida albicans, in its resistance form, is found in up to $80 \%$ of human population, not necessarily producing any harmful effect, but alterations in the profile of this association may cause candidiasis ${ }^{(6)}$.

Candidiasis is the most common fungal infection in the oral cavity, and is mainly caused by Candida albicans. The dorsal surface of the tongue seems to be an important reservoir ${ }^{(6,16,31)}$. The prevalence of Candida spp. in the oral cavity of clinically normal patients ranges from $3 \%$ to $48 \%$; it is found in healthy

First submission on $02 / 04 / 14$; last submission on 19/08/14; accepted for publication on 22/09/14; published on 20/10/14

1. Master's degree in Pathology from Universidade Federal Fluminense (UFF); professor at Universidade Estácio de Sá and Faculdade Souza Marques; cytotechnologist at the Brazilian National Cancer Institute (INCA).

2. Doctorate in Pathology from UFF; assistant professor at UFF.

3. Master's degree in Pathology from UFF; professor at Associação Brasileira de Odontologia do Rio de Janeiro (ABORJ).

4. Doctorate in Pathology from UFF; associate professor at UFF.

5. Doctorate in Pathology from UFF; associate professor at UFF; vice-coordinator at the Post-Graduate Program in Pathology of UFF. 
children, young adults and, with a higher prevalence, in hospitalized patients ${ }^{(4,34,35)}$. Oral candidiasis has a variable clinical presentation, and its diagnosis is based on symptoms and clinical aspects, in association with medical history $33,24,36,39,45)$. In its pseudomembranous form it is easily diagnosed, although in erythematous and hyperplastic forms, angular cheilitis and median rhomboid glossitis, the clinical aspects are not always enough for diagnosis, with the use of additional methods being necessary for diagnostic confirmation ${ }^{(13,17,18,23)}$.

Diagnostic methods include direct examination, culture, cytopathologic analysis and the histopathologic examination $^{(5,16,45,46,55)}$. In direct examination, the material collected from scraping the affected area is placed on a glass slide, and then the addition of a drop of $20 \%$ potassium hydroxide (KOH) destroys epithelial cells on the smear, permitting to view yeasts and hyphae, which are more resistant. A coverslip is immediately placed over the material, gently heated with a Bunsen flame before going through microscopic examination ${ }^{(47,}$ 49). These are considered disadvantages of direct examination: non identification of the other elements of the material, impossibility of future registration by image capturing, and difficulty in the identification of microorganisms ${ }^{(29)}$. The culture is, in general, used for the specific diagnosis of most part of fungi, with the Sabouraud dextrose agar being the most commonly used culture medium, because it is selective; identification of the fungus is made by its morphological characteristics, its biochemical characteristics and its antigenic structure ${ }^{(43)}$. However, a positive culture in the absence of direct examination to identify pathogenic forms (hyphae and pseudohyphae) does not necessarily mean the presence of the disease, since Candida spp. yeasts may be found in the normal flora of the skin and mucosae ${ }^{(21,52)}$. Besides, it is a method not available in all clinical laboratories, and whose result requires days ${ }^{(15,55)}$. Biopsy is particularly useful for the diagnosis of chronic hyperplastic candidiasis. The slides stained by the periodic acid-Schiff (PAS) or Grocott methods allow quick and easy identification of all morphological forms of Candida spp. ${ }^{(28,55)}$.

Cytopathology is an innocuous method, material collection is of low complexity and can be made at home, in public campaigns, in outpatient departments, in the laboratory or at the bedside and, although dependent on a specialized evaluator, it represents a reliable mode of diagnosis as, besides identification of the pathogenic forms of Candida spp. it permits the assessment of inflammatory alterations associated with candidiasis ${ }^{(37,38,43)}$. The most used staining method in cytopathology is Papanicolaou, which easily permits the diagnosis of candidiasis in lesions with large amounts of fungi (as in the pseudomembranous candidiasis). But in the other forms of oral candidiasis, the small number of hyphae and pseudohyphae may hamper the cytopathologic diagnosis of candidiasis: the use of stains that make identification of Candida spp. easier is indispensable ${ }^{(1,4,15,40)}$. PAS is used to identify glycogen in the cells, detects the aldehyde produced by oxidation with the periodic acid, which, in the presence of the Schiff's reagent (pararosaniline and sodium metabisulfite), forms an intracellular complex colored in magenta that reacts with cytoplasmic deposits of carbohydrates, mucopolysaccharides and glycoproteins ${ }^{(25)}$. The morphological structures of Candida spp. are easily identified by the method, which stains the carbohydrates existing in great quantities in fungal cell walls. Because of that, in cytopathology, PAS is considered the best method for identification of Candida spp., although little used for its higher cost in comparison with other staining methods ${ }^{25,41,}$ ${ }^{43}, 51$. Gram's method is frequently used in the laboratory routine because it is fast and inexpensive. It was described in 1884 by the Danish physician Hans Christian Joachim Gram to differentiate bacteria that possess distinct cell wall structures ${ }^{(30)}$. All fungi are gram-positive, therefore the use of this stain enables the recognition of the morphologic forms of Candida spp., as well as it permits the identification and the differentiation of gram-positive and gramnegative bacteria in the sample ${ }^{(22,26,29)}$.

The objectives of this work were to assess sensitivity and specificity of Gram's method in identifying pathogenic forms of Candida spp. and to evaluate the degree of concordance between the clinical and the cytopathological methods in the diagnosis of oral candidiasis.

The sample was formed by 171 smears from 42 psoriatic patients seen at the outpatient department of Hospital Universitário Antônio Pedro of Universidade Federal Fluminense (HUAP/UFF). The study was approved by the Ethics Committee (report $n^{0}$. 291/2010), and all patients signed the informed consent. Participants had their data, such as sex and age, collected, and underwent an intraoral physical examination for documentation of the identified alterations. Material from the dorsal surface of the tongue was collected from each of the 42 participants, and in 15 of them the palate was also scraped. A sterile brush (Kolplast ${ }^{\circledR}$, Brazil) was used to scrape a same area ( 42 for the tongue and 15 for the palate), and the samples were transferred to slides adequately identified by the method of smear confection, immediately immersion-fixed in hydrated alcohol $\left(96^{\circ} \mathrm{GL}\right)$, prior to staining and analysis at the Anatomic Pathology Service of HUAP/UFF. Smears of each area were stained by Papanicolaou $(n=57)$, PAS $(n=57)$ and Gram $(n=57)$ methods. Blind analysis was carried out by an experienced professional and by the cytopathologist responsible for the study, at a binocular microscope, with $10 \times, 20 \times$ and $40 \times$ objective lenses.

The identification of Candida spp. was based on the presence of its morphological structures (yeasts, hyphae and 
pseudohyphae), and for the diagnosis of candidiasis the sum analysis of Papanicolaou and PAS or Gram (Figure 1) stained slides was considered.

The collected data were tabulated in software Microsoft Excel. So as to comparatively analyze the diagnostic quality of Gram and PAS methods, diagnostic tests used the parameters specificity, sensitivity, positive predictive value (PPV), negative predictive value (NPV), prevalence, accuracy (correct classification), incorrect classification and likelihood ratio (for positive and negative result). A paired analysis was performed comparing results for material from the different anatomical regions; chi-squared test was used, with $p<0.05$ considered statistically significant
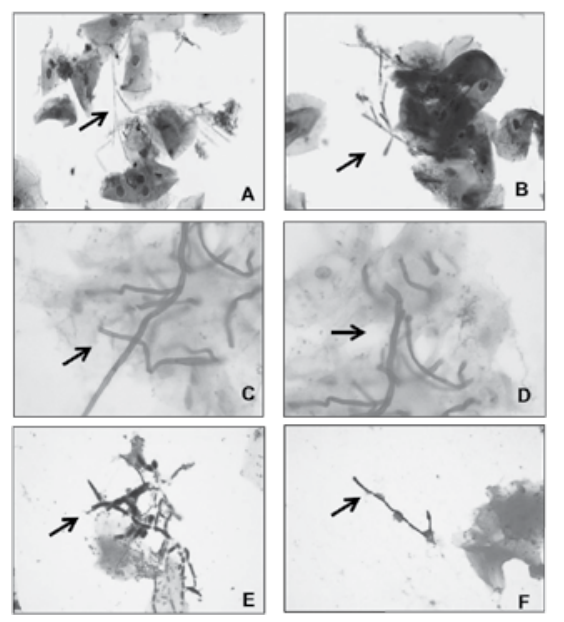

FIGURE 1 - Photomicrographs of Candida spp. morphological structures. Original magnification 400 $\times(40 \times$ objective lens and $10 \times$ ocular lens). $A$ and B) Papanicolaou staining; $C$ and D) PAS staining; $E$ and F: Gram staining

PAS: periodic acid-Schiff; HUAP/UFF: Hospital Universitário Antônio Pedro/Universidade Federal Fluminense.

Source: Pathological Anatomy Service/HUAP/UFF.

\section{RESULTS}

The profile of the 42 participants in the research was characterized as mean age of 60 years (range 26-91years); 22 (52\%) were males; eight (19\%) patients had clinical diagnosis of candidiasis; seven (17\%) had other diagnoses; and 27 (64\%) had normal mucosa (Table 1).

Conventional cytopathological analysis of the 57 smears stained by Papanicolaou technique revealed 19 (33\%) smears with candidiasis and 38 (67\%) within the normal limits. The positivity total for Candida spp. in the 57 smears stained by PAS was 28 (49\%); by Gram, 21 (37\%). This was a non-significant difference $(\phi=0.8642>0.05)$. The comparative analysis between the methods revealed that in PAS there was higher prevalence of Candida spp. (12\%) than in Gram's. The comparative analysis of the 42 tongue smears and the 15 palate smears (PAS and Gram) indicated a frequency of candidiasis of $50 \%$ and $73 \%$, respectively, non significant $(p=0.9854 ; p>0.05)$. By analyzing tongue and palate smears separately, candidiasis was more prevalent in the palate (Table 2). The concordance analysis of the 57 smears (PAS + Gram) in relation to the clinical analysis revealed that among the 14 (25\%) scrapes from areas with clinical features of candidiasis, diagnosis was confirmed in 13 (93\%). In cases in which clinical presentation was negative for candidiasis, 19 (33\%) cases of candidiasis were found in cytopathology.

Based on the PAS staining (gold standard), one observes that Gram's method presents high sensitivity level (81.6\%), high specificity (71.4\%), average PPV (64.3\%), high NPV (86.2\%), accuracy that indicates an average correct classification (75.4\%) with likelihood results (which assess the possible variations in probability values estimated by diagnostic tests) within an acceptable context, what means that variations in the expected probabilities are small and little significant (Figure 2). Results presented chi-squared $=2.27$ and g.l $=3$ with $p=0.193>0.05$, what proves there are no significant differences in the results of the different material types. This result integrates the assertive

TABLE 1 - Sample distribution according to clinical characteristics

\begin{tabular}{cccc}
\hline Candidiasis (clinical) & Other diagnoses & Normal mucosa & Total \\
\hline $5(12 \%)$ & $1(2.5 \%)$ & $14(33 \%)$ & $20(48 \%)$ \\
$3(7 \%)$ & $6(14.5 \%)$ & $13(31 \%)$ & $22(52 \%)$ \\
$8(19 \%)$ & $7(17 \%)$ & $27(64 \%)$ & $42(100 \%)$ \\
\hline
\end{tabular}

TABLE 2 - Comparative analysis of cytopathological diagnoses of candidiasis

\begin{tabular}{|c|c|c|c|c|c|c|}
\hline \multirow{2}{*}{ Material } & \multicolumn{2}{|c|}{ PAS } & \multicolumn{2}{|c|}{ GRAM } & \multicolumn{2}{|c|}{ Pap } \\
\hline & + & - & + & - & + & - \\
\hline Tongue $(n=42)$ & $18(43 \%)$ & $24(57 \%)$ & $13(31 \%)$ & $29(69 \%)$ & $12(29 \%)$ & $30(71 \%)$ \\
\hline Palate $(n=15)$ & $10(67 \%)$ & $5(23 \%)$ & $8(53 \%)$ & $7(47 \%)$ & $7(47 \%)$ & $8(53 \%)$ \\
\hline Palate + tongue & $28(49 \%)$ & $29(51 \%)$ & $21(37 \%)$ & $36(63 \%)$ & $19(33 \%)$ & $38(67 \%)$ \\
\hline$(n=57)$ & \multicolumn{2}{|c|}{$57(100 \%)$} & \multicolumn{2}{|c|}{57 (100\%) } & \multicolumn{2}{|c|}{$57(100 \%)$} \\
\hline
\end{tabular}

PAS: periodic acid-Schiff; Pap: Papanicolaou method. 
Diagnostic tests Gram and PAS

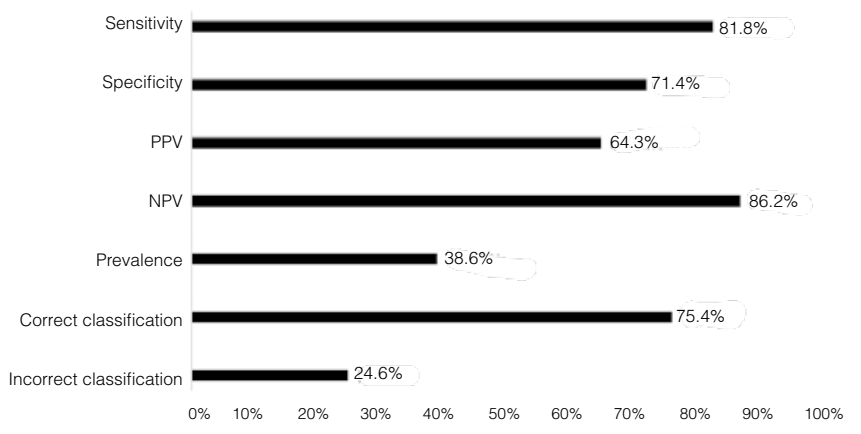

FIGURE 2 - Statistical analysis of Gram's method in relation to PAS

PAS: periodic acid-Schiff; PPV: positive predictive value; NPV: negative predictive value.

guidance on not considering the material type a discretionary factor, since results are concordant between sample types.

Results of diagnostic tests, by sex, also presented values that denote the reliability of Gram's method, in comparison with the gold-standard protocol PAS. Nevertheless we must highlight that the indices of diagnostic factors are all higher for males than for females.

\section{DISCUSSION}

Several authors report the high prevalence of Candida spp. in healthy and asymptomatic populations ${ }^{(4,26,34,40}$. According to Odds (1994), the diagnosis of oral candidiasis cannot be made adequately only by clinical findings: it must be based on the presence of clinical signs allied to the observation of hyphae or pseudohyphae at cytopathologg( ${ }^{(32)}$. In spite of the importance of cytopathology as a diagnostic method for oral candidiasis, its use is not frequent in clinical practice and in the literature; in most studies the used method is the fungal culture ${ }^{(1,3,7,14)}$.

Although the results of this study have revealed a strong association between clinical and cytopathologic diagnosis, all participants are psoriatic patients, part of a group carefully investigated and were examined by experienced stomatologists. We also highlight the elevated percentage of false negative cases for Candida spp. The degree of concordance between clinical and cytopathological diagnosis proved to be high in cases of clinically suspected oral candidiasis, and low when there was no clinical suspicion.

Candida spp. are oval yeasts of around five micrometers. Their primary structures are cells that reproduce by budding, single or multiple, generally round-shaped (spores, asexual in origin), called blastoconidia ${ }^{(6)}$. They can also germinate as filamentous structures (hyphae). In between these two processes (budding and filamentation) the fungus may exhibit other forms, as pseudohyphae that, in reality, are elongated yeasts joined together ${ }^{(0,10,51)}$. The criterion to differentiate between a true hypha and a pseudohypha is the observation of the germ tube formation (true hypha) from the yeast cell, and of the presence of septa. Pseudohyphae have a constriction between the mother cell and the filament length ${ }^{(6,51)}$. The hypha, due to its filamentous development, is the structure that best crosses barriers; and yeasts, for their round shape, are the best for an efficient dissemination. In general, the spore shape predominates during colonization in the healthy host, while hyphae grow at immune system deficiency, characterizing a profile of invasive potential ${ }^{(6,42)}$. Accordingly, both forms are of great importance in pathogenesis, as they are required in different situations in the host ${ }^{(6)}$.

Cytopathology presents high specificity for the diagnosis of candidiasis $^{(27,34)}$, still its use for the diagnosis of oral lesions and infections is not very frequent among dental surgeons ${ }^{(41,44)}$. Whereas oral cytopathology can be performed with material obtained by different methods, the technique that best provides quality material is the scrape, a process of mechanical separation of epithelium that can be made with different instruments ${ }^{(2,4)}$. The oral site that presents the largest number of lesions infected by Candida spp. is the tongue, followed by buccal mucosa and gingiva $^{(4,48,50)}$. According to Arendorf and Walker (1980), the tongue and the labial mucosa are the most vulnerable areas to the fungal infection. McIntyre (2001) ${ }^{(29)}$ described the most common type of candidiasis, the pseudomembranous, which affects principally soft palate, tongue, pharynx, buccal mucosa and gingiva ${ }^{(4,7,29,54)}$. In our study, we obtained scrapes from the tongue, for it represents the main reservoir of Candida spp.; and from the palate, in patients with clinical suspicion of candidiasis.

A number of oral diseases are possibly identifiable by cytological examinations ${ }^{(16)}$, however collection, preparation, and analysis of the cytopathological material demand effective training in order to avoid failures ${ }^{(38)}$. For the cytopathological diagnosis of oral candidiasis, the use of the adequate collection technique is necessary, as well as the rapid and efficacious identification: they provide safe results and appropriate treatment ${ }^{(14,34)}$. The material may be stained by the Gram or PAS methods to verify, for example, the presence of microorganisms, like Candida spp., through the identification of its morphological structures, mainly the hypha ${ }^{(41)}$.

Several studies have been conducted to compare the Gram test with other staining methods in the identification of microbiota, revealing high sensitivity in the detection of fungi 
and bacteria ${ }^{(8,12,27,41)}$. Then again, PAS is proven to have greater sensitivity in the identification of Candida spp. structures ${ }^{(34,54)}$. The method presents high sensitivity and specificity for the diagnosis of oral candidiasis ${ }^{(8)}$, for this reason it was chosen as gold standard for cytopathological analysis. Based on our findings, we may say that the Gram method is adequate and concordant with PAS method, yet, due to the size of our sample, it is relevant to carry out more studies to assess Gram's method sensitivity for the analysis of oral candidiasis.

Given the high frequency of Candida spp. associated with clinically healthy individuals, an efficient and rapid laboratory diagnosis is necessary. Cytopatholgy is indicated as an efficient method. It easily shows the structures of Candida spp. by using PAS staining, which reacts with some polysaccharides of the fungus, making it positive in relation to the other microscopic structures $^{(53)}$. Cytopatholgy enables the diagnosis of not clinically detected oral candidiasis, and evaluates the clinical diagnosis of candidiasis $^{(42)}$.

\section{CONCLUSION}

The obtained results confirm that PAS is the best method for the diagnosis of oral candidiasis, but Gram staining proved adequate, being necessary to intensify professional training for identification of the fungus morphological structures. Although Papanicolaou is the most frequently used method in cytopathological routine, for it permits the analysis of cellular alterations of inflammatory and neoplastic nature for the diagnosis of candidiasis, PAS used in association is also indicated. Thus, we suggest that the diagnosis of candidiasis is established by means of clinical evaluation associated with cytopathological analysis, based on the presence of hyphae and/or pseudohyphae and on inflammatory alterations.

\section{RESUMO}

Introdução: Espécies de Candida fazem parte da microbiota normal de indivíduos sadios, residindo como comensais. Entretanto, podem tornar-se patogênicas caso ocorram alterações nos mecanismos de defesa do hospedeiro ou comprometimento das barreiras anatômicas. A candidíase é a infecção fúngica mais frequente na mucosa oral, causada principalmente pela Candida albicans. O diagnóstico baseia-se nos aspectos clínicos e nos sintomas, em conjunto com os métodos laboratoriais. Objetivos: Avaliar a sensibilidade e a especificidade do método de Gram na identificação da Candida spp. em raspados de mucosa oral e avaliar o grau de concordância entre os métodos clínico e citopatológico no diagnóstico de candidíase oral. Material e métodos: Teste cego de 171 esfregaços, provenientes dos pacientes atendidos no Hospital Universitário Antônio Pedro da Universidade Federal Fluminense (HUAP/UFF), corados pelas colorações de Gram ( $\mathrm{n}=57)$, ácido periódico de Schiff (PAS) ( $\mathrm{n}=57)$ e Papanicolaou ( $\mathrm{n}$ =57). Resultados: A análise comparativa entre os métodos revelou que no PAS bá maior prevalência de Candida spp. (12\%) em relação ao Gram; todavia, não há diferença significativa entre os resultados. Dos casos com diagnóstico clínico de candidíase, 93\% foram confirmados pela citopatologia. Conclusão: A coloração pelo Gram mostrou-se adequada, sendo necessário intensificar o treinamento do profissional para a identificação das estruturas morfológicas do fungo. Apesar de o Papanicolaou representar o método mais utilizado na rotina citopatológica para diagnóstico da candidíase, também se indica a utilização do PAS concomitantemente. Desse modo, sugere-se que o diagnóstico de candidiase seja realizado por meio de avaliação clínica associada à análise citopatológica, com base na presença de hifas e/ou pseudo-hifas.

Unitermos: citopatologia oral; candidíase; Candida spp.; PAS; Gram; Papanicolaou.

\section{REFERENCES}

1. ABU-ELTEEN, K. H.; ABU-ALTEEN, R. M. The prevalence of Candida albicans populations in the mouths of complete denture wearers. New Microbiol, v. 21, n. 1, p. 41-8, 1998.

2. ACHA, A. et al. Aplicaciones de la citologia oral por raspado (exfoliativa) en el cáncer y precáncer oral. Med Oral Patol Oral Cir Bucal, v. 10, n. 2, p. $95-102,2005$.
3. AKPAN, A.; MORGAN, R. Oral candidiasis. Postgrad Med J, v. 78, p. 455$9,2002$.

4. ARENDORF, T. M.; WALKER, D. M. The prevalence and intra-oral distribution of Candida albicans in man. Arch Oral Biol, v. 25, n. 1, p. 1-10, 1980.

5. BAANDRUP, U. Sampling, sampling errors and specimen preparation. Acta Cytol, v. 44, n. 6, p. 944-8, 2002.

6. BARBEDO, L. S.; SGARBI, D. B. G. Candidíase. J Bras Doenças Sex Transm, v. 22, n. 1, p. 22-38, 2010. 
7. BERNSTEIN, M. L.; MILLER, R. L. Oral exfoliative cytology.J Am Dent Assoc, v. 96, n. 4, p. 625-9, 1978.

8. BHAVASAR, R. S. et al. Detection of candida by calcofluor white. Acta Cytol, v. 54, n. 5, p. 679-84, 2010.

9. BR00KS, G. F. et al. Microbiologia médica. 20. ed. Rio de Janeiro: Guanabara Koogan, 1998.

10. CALDERONE R. A.; CLANCY, C. J. Candida and candidiasis. 2. ed. Washington: ASM Press, 2012.

11. CANNON, R. D. et al. Oral candida: clearance, colonization or candidiasis? J Dent Res, v. 74, n. 5, p. 1152-61, 1995.

12. CARNEIRO, S. S. et al. Contribuição da citologia de Papanicolaou para o diagnóstico de leveduras em secreção vaginal.J Bras Doenças Sex Transm, v. 18, n. 1, p. 36-40, 2003.

13. CHIMENOS, E. et al. Antifungal drugs in the management of mycosis. Med Oral, v. 3, n. 2, p. 78-90, 1998.

14. COSTA, K. R. C.; CANDIDO, R. C. Diagnóstico laboratorial da candidíase oral. NewsLab, v. 83, p. 138-45 2007.

15. DARWAZEH, A. M.; AL-BASHIR A. Oral candidal flora in healthy infants.J Oral Pathol Med, v. 24, n. 8, p. 361-4, 1995.

16. DIAS, E. P. Diagnóstico clínico e cito-histopatológico das manifestações bucais na AIDS.J Bras Doenças Sex Transm, v. 10, n. 1, p. 10-6, 2008.

17. FARAH, C. S. et al. Oral fungal infections: an update for the general practitioner. Aust Dent J, v. 55, Suppl. 1, p. 48-54, 2010.

18. FAVEL, A. et al. Susceptibility of clinical isolates of Candida lusitaniae to five systemic antifungal agents. J Antimicrob Chemoth, v. 53, n. 3, p. 526-9, 2004.

19. GREENSPAN, D. Treatment of oropharyngeal candidiasis in HIVpositive patients. J Am Acad Dermatol, v. 31, n. 3, Pt.2, p. S51-5, 1994.

20. GUERREIRO, H. M. N. et al. Flora vaginal e correlação com aspectos citológicos. Rev Saúde Publ, São Paulo, v. 20, n. 6, p. 415-20, 1986.

21. HANEL, H. et al. High phospholipase-A activity of Candida albicans isolated from the intestine of psoriatic patients. Mycoses, v. 131, n. 9 , p. 451-3, 1988.

22. HOFFMAN, H.; SIMON, J. C. Gram-staining mechanism of superficial oral epithelial cells. J Dent Res, v. 48, n. 3, p. 390-5, 1969.

23. JÄRVENSIVU, A. et al. Candida yeasts in chronic periodontitis tissues and subgingival microbial biofilms in vivo. Oral Dis, v. 10, n. 2, p. 10612, 2004.

24. KESSEL, L. J; TAYLOR, N. Chronic mucocutaneous candidiasis treatment of the oral lesions with miconazole - two case reports. $\mathrm{Br} J$ Oral Surg, v. 18, n. 1, p. 51-6, 1980.

25. LAMEY, P. J.; SAMARANAYAKE, L. P. Oral candidosis: diagnosis and management. Dent Update, v. 15, p. 328-31, 1988.

26. LYNCH, D. P. Oral candidiasis. History, classification and clinical presentation. Oral Surg Oral Med Oral Pathol, v. 78, n. 2, p. 189-93, 1994.

27. MARTINS, M. C. L. et al. Avaliação do método de Papanicolaou para triagem de algumas infecções cérvico-vaginais. $R B A C$, v. 39, n. 3, p. 217 21, 2007.

28. McCUllough, M. J.; SAVAGET, N. W. Oral candidosis and the therapeutic use of antifungal agents in dentistry. Aust Dent J, v. 50, n. 4, Suppl. 2, p. 4, 2005.
29. McINTYRE, G. T. Oral candidosis. Dent Update, Guildford, v. 28, n. 3, p. 132-9, 2001

30. MINISTÉRIO DA SAÚDE, BRASIL. Secretaria de Políticas de Saúde Programa Nacional de DST e AIDS. Técnica de coloração de Gram. 2001, Brasília.

31. NEVILLE, B. W. et al. Patologia oral \& maxilofacial. 2. ed. Rio de Janeiro: Gruanabara Koogan, 2004.

32. ODDS, F. C. Pathogenesis of Candida infection.J Am Acad Dermatol, n. 31, p. S2-S5, 1994.

33. PARDI, G. et al. Detection of Candida species in patients with denture stomatitis. Acta Odontol Venez, v. 39, n. 3, p. 32-44, 2000.

34. PICCIANI, L.V.S. et al. Oral candidiasis in patients with psoriasis: correlation of oral examination and cytopathological evaluation with psoriasis disease severity and treatment. J Am Acad Dermatol, v. 68, n. 6, p. 986-91, 2013.

35. QI, Q. G. et al. Frequency, species and molecular characterization of oral Candida in hosts of different age in China.J Oral Pathol Med, v. 34, p. 352-6, 2005

36. RADOS, P. V. et al. Citologia esfoliativa da cavidade oral. $R$ Fac Odontol, Porto Alegre, v. 40, n. 1, p. 53-9, 1999.

37. REGEZI, J. A.; SCIUBBA, J. J. Patologia bucal. Correlações clínicopatológicas. 3. ed. Rio de Janeiro: Guanabara Koogan, 2000. p. $97-102$.

38. RICHARDSON, M. D.; WARNOCK, D. W. Fungal infection diagnosis and management. Oxford: Blackwell Scientific, 1993.

39. RUHNKE, M. et al. Diagnosis and therapy of Candida infections: joint recommendations of the German Speaking Mycological Society and the Paul-Ehrlich-Society for Chemotherapy. Mycoses, v. 54, n. 4, p. 279-310, 2011.

40. SAMARANAYAKE, Y. H.; SAMARANAYAKE, L. P. Experimental oral candidiasis in animal models. Clin Microbiol Rev, v. 14, n. 2, p. 398-429, 2001.

41. SANDRIN, R. et al. Comparação entre a citologia em base líquida e a citologia esfoliativa convencional no diagnóstico da candidose bucal. Rev Odontol UNESP, Araraquara, v. 39, n. 1, p. 33-9, 2010.

42. SANTOS, B. M. Investigação da candidíase oral em pacientes portadores de psoríase: estudo clínico e citopatológico. 2013. 91f. Dissertação (mestrado em Patologia) - Programa de Pós-graduação em Patologia da Universidade Federal Fluminense, Niterói, 2013.

43. SCALERCIO, M. et al. Estomatite protética versus candidíase: diagnóstico e tratamento. $R G O$, Porto Alegre, v. 55, n. 4, p. 395-8, 2007.

44. SCHMID, J. et al. Evidence for a general-purpose genotype in Candida albicans, highly prevalent in multiple geographical regions, patient types and types of infection. Microbiology, v. 145, pt. 9, p. 2405-13, 1999. 45. SCULLY, C. et al. Candida and oral candidosis: a review. Crit Rev Oral Biol Med, v. 5, n. 2, p. 125-57, 2004.

46. SHARON, V.; FAZEL, N. Oral candidiasis and angular cheilitis. Dermatol Ther, v. 23, n. 3, p. 230-42, 2010.

47. SILVERMAN, J. et al. Laboratory diagnosis of oral candidosis. In: SAMARANAYAKE, L. P.; MACFARLANE, T. W. (Eds.). Oral candidosis. London: Butterworth, 1990. 
48. SLOTS, J. et al. Yeasts, enteric rods and pseudomonads in the subgingival flora of severe adult periodontitis. Oral Microbiol Immunol, v. 3, n. 2, p. 47-52, 1988.

49. SLOTS, J.; TAUBMAN, M. A. Contemporary oral microbiology and immunology. St. Louis: MosbyYear Book, 1992.

50. SOYSA, N. S. et al. Antimicrobials as a contributory factor in oral candidosis - a brief overview. Oral Dis, v. 14, n. 2, p. 138-43, 2008.

51. SUDBERY, P. et al. The distinct morphogenic states of Candida albicans. Trends Microbiol, v. 12, n. 7, p. 317-24, 2004.

52. TERAI, H.; SHIMAHARA, M. Usefulness of culture test and direct examination for the diagnosis of oral atrophic candidiasis. Int $J$ Dermatol, v. 48, n. 4, p. 371-3, 2009.

53. URIZAR, J. M. A. Candidiasis orales. Rev Iberoam Micol, v. 19, p. 1721, 2002.

54. VALADARES, C. P. Diagnóstico citopatológico da leucoplasia pilosa oral em pacientes portadores de HIV-1: análise comparativa entre citopatologia oral e a citologia em meio líquido. 2006. 136 f. Dissertação (mestrado em Patologia) - Programa de Pós-graduação em Patologia da Universidade Federal Fluminense, Niterói. 2006.

55. WILLIANS, D. W.; LEWIS, M. A. Isolation and identification of Candida from the oral cavity. Oral Dis, v. 6, n. 1, p. 3-11, 2000. 